Vol. 2 No. 2, Desember 2018, 167-183

P-ISSN: 2549-208X

\title{
مفهوم التلاوة والتزكية والتعليم في القرآن الكريم
}

\author{
Muhammad Ripal \\ SMP Al-Azhar Syifa Budi Parahyangan Bandung Barat \\ Coresponding Email: muhamadripal61@yahoo.com
}

\begin{abstract}
ملخص البحث
هناك اندماج ألفاظ التّلاوة والتّكية والتّعليم في أربعة مواضع من القرآن المجيد، فقد وردت في سورة

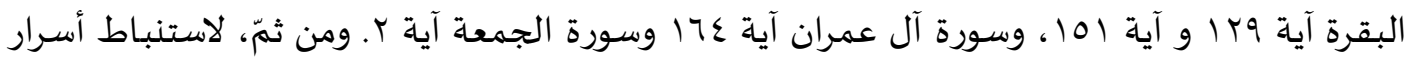

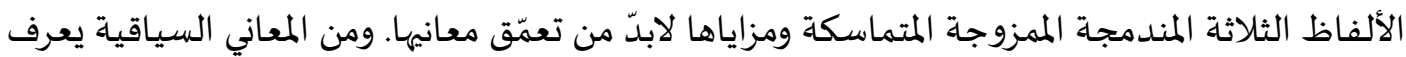
أن لفظ التلاوة الذي يقرنه لفظ الآية أنّه قراءة القرآن المجيد وتوجياه النفوس إلى الاستفادة منه والاعتبار

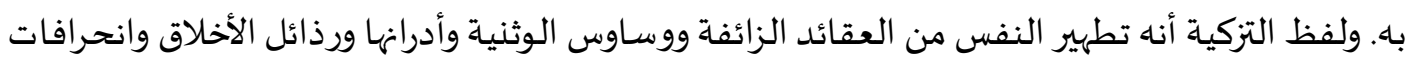
الجاهلية. ولفظ التعليم الذي يقرنه الكتاب أنّه تفهيم ألفاظ القرآن والأمر بحفظ ألفاظه ونظمها لتكون معانيه حاضرة وتبيين ما فيه من الفرائض والأحكام والسنن وشرائع الأنبياء، ولفظ التعليم الذي يقرنها الحكمة أنه الإيقاف على سنة الرسول العملية وسيرته صلوات الله وسلامه عليه وباختصيار القول إنّه الارشاد العملي. الكلمات الرئيسية: تلاوة، تزكية، تعليم، القرآن الكريم.
\end{abstract}

\begin{abstract}
Abstrak
Aspek bahasa merupakan salah satu lingkup kemukjizatan al-Qur'an. Kontruksi lahir dari kitab suci ini adalah berbahasa Arab, hal tersebut sangat relevan dengan beberapa firman Allah SWT. Setiap orang yang memusatkan perhatiannya terhadap al-Qur'an, maka dia akan menemukan berbagai aspek dari kemukjizatan al-Qur'an tersebut, diantaranya setiap kata yang berada dalam susunan suatu ayat merupakan mukjizat yang diperlukan oleh kata lainnya dalam ayat tersebut yang telah terkombinasi atau terangkai dengan sempurna. Hal demikian yang ditemukan oleh peneliti dalam al-Qur'an, adanya rangkaian kata Tilâwah, Tazkiyah dan Ta'lim dalam berbagai ayat berikut, yaitu surat al-Bâqarah, 2: 129, 151, âli-Imran, 3: 164, dan alJumu'ah, 62: 2.
\end{abstract}

Kata Kunci: Tilâwah, Tazkiyah, Ta'lim dan al-Qur'an. 
كان القرآن الكريم تحدى به النبي صلوات الله وسلامه عليه العرب وقد عجزوا عن

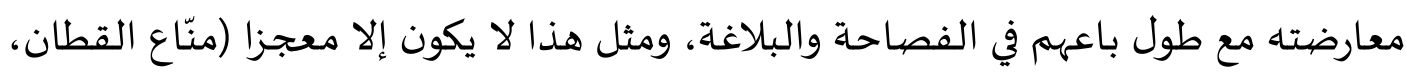

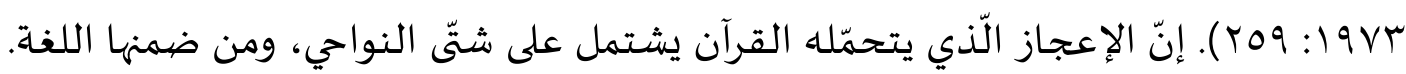

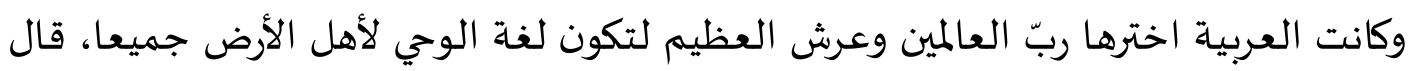

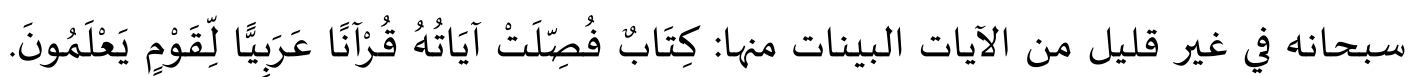

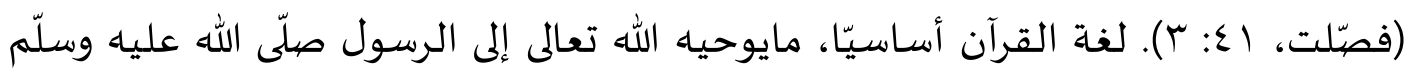

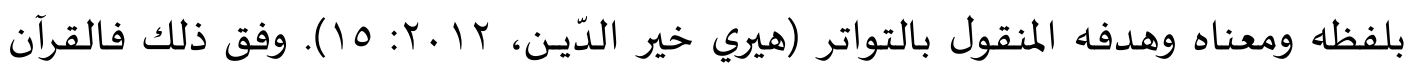

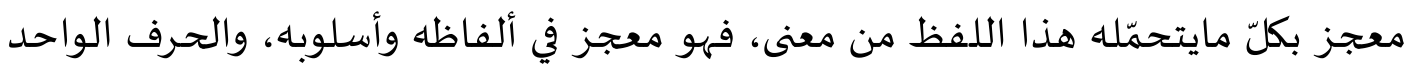

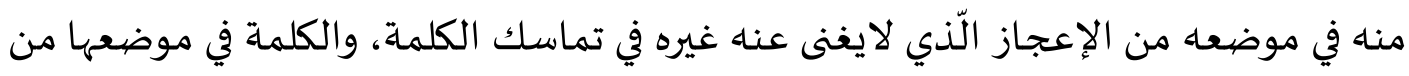

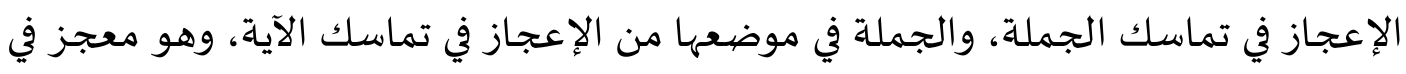

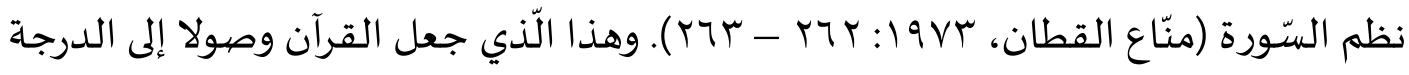
العالية من ناحية لغته الفريدة البديعة في تأليف الحروف والكلمة والجملة في تماسك الآيات.

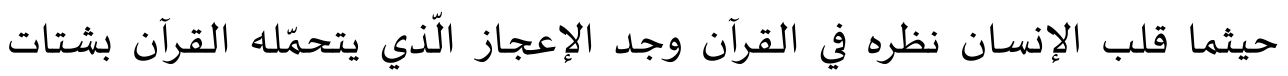

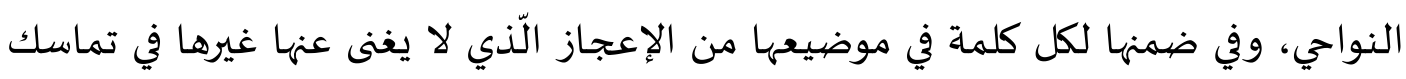

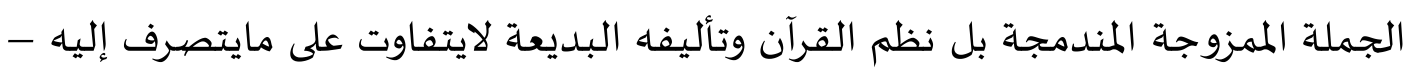
كماسبقت الإشارة إليه.

وكذلك الشّّأن في اختراع الباحث نحو القرآن، هناك اندماج ألفاظ التّلاوة والتّزكية

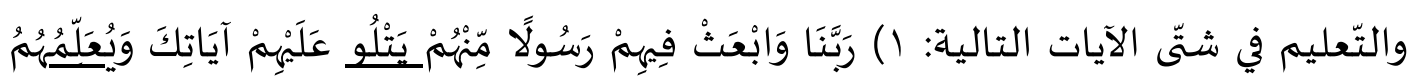

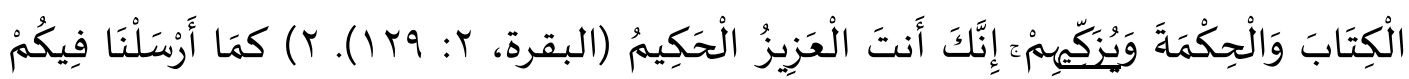

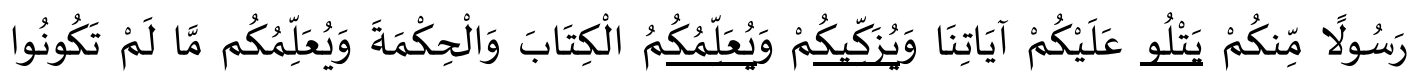

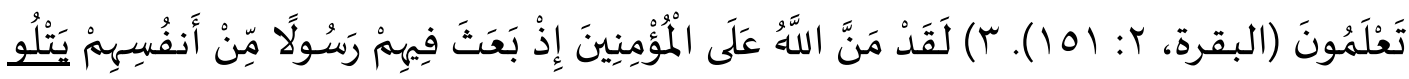

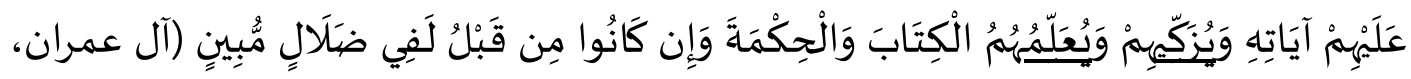

كان اندماج ألفاظ التلاوة والتزكية والتعليم تكرر في أربعة مواضع من سور ثلاث مع

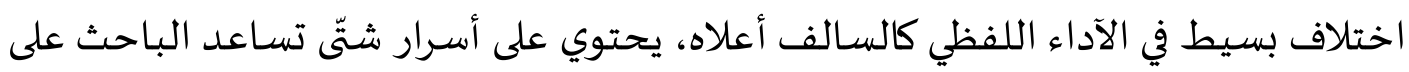

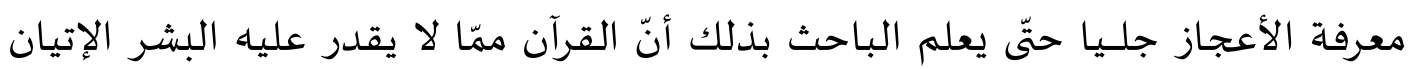


بمثله. ومن ثمّ، لاستنباط أسرار اندماج ألفاظ التلاوة والتزكية والتعليم ومزاياها من الإعجاز

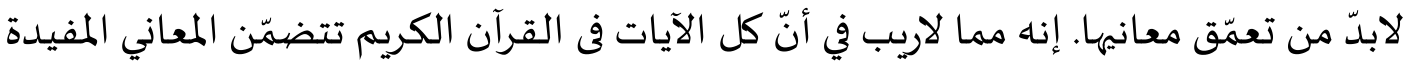

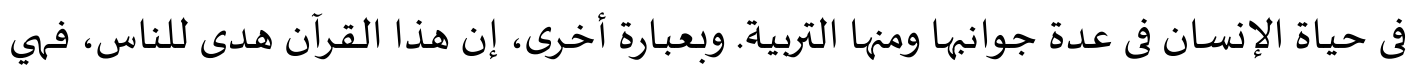

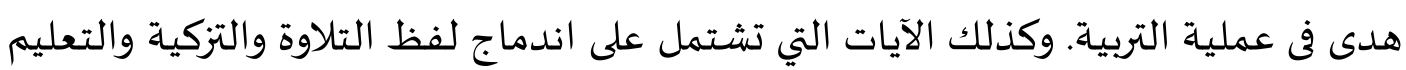
فى القرآن لها المعاني المفيدة في عملية التربية.

ومن ثمّ، أغراض البحث فهي () معرفة المعانى المعجمياة لألفاظ التلاوة والتزكية

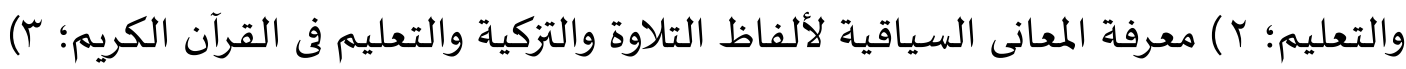

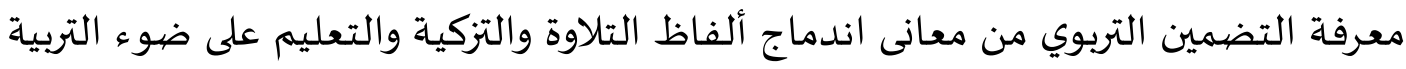
الإسلامية.

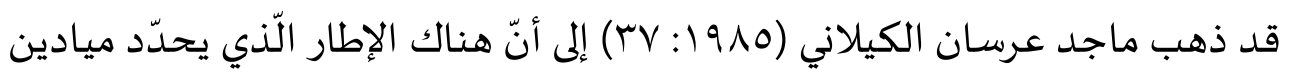
التربية الإسلامية ومناهجها يتمثل في قوله جلّ وعلا السّابق ذكره أعلاه وهو في سور ثلاث

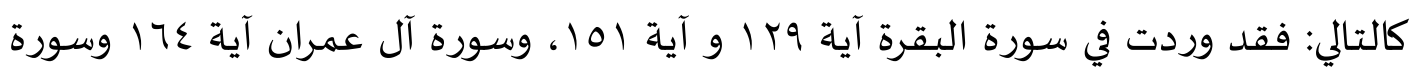

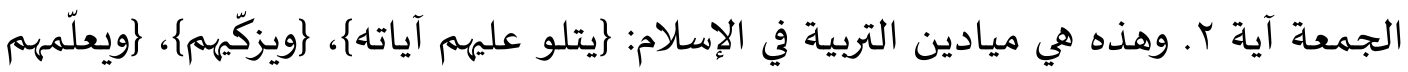

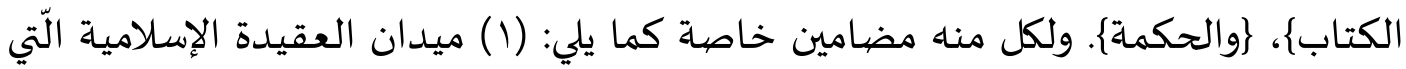

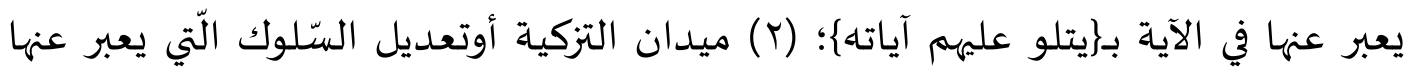

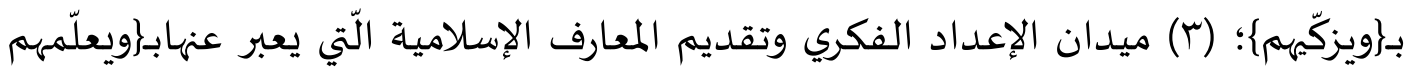

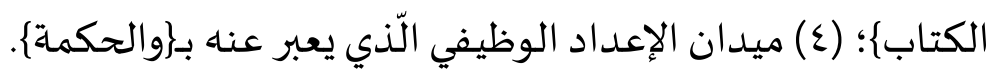

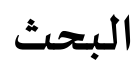

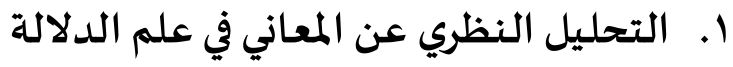
إنّنا على علم أن أهم الموضيوع لعلم الدلالة هو المعنى. والمراد بالمعنى من وجهالئ نظر

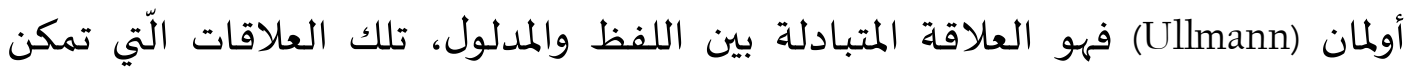
أحدهما من استدعاء الآخر. والمعنى عند بلومفيلد (Bloomfield) فهو مجموعة الحوادث

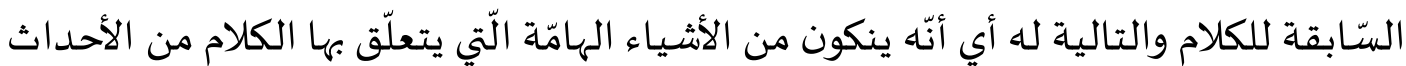

$$
\text { العلميّة (فريد عوض حيدر، } 0 \text {. . ب: } 9 \text { 1). }
$$

وللمعنى خمسة أنواع، كما قد أشار إليه أحمد مختار عمر في كتاباه علم الدلالة

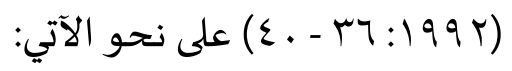




\section{أ. المعنى الأسـاسي (Basic Meaning)}

المعنى الأسـاسي أو المعنى الأولي أو المركزي يسمى أحيانا بالمعنى التصوري أو

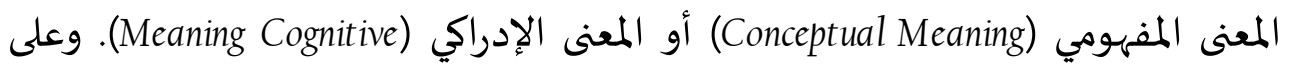

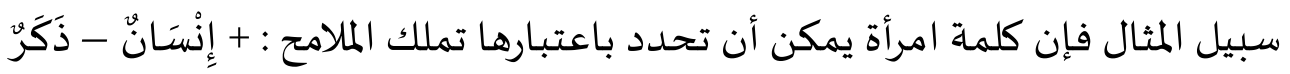

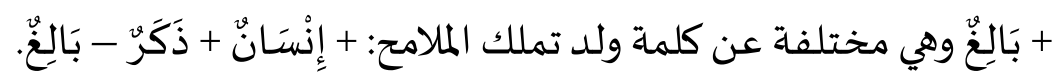

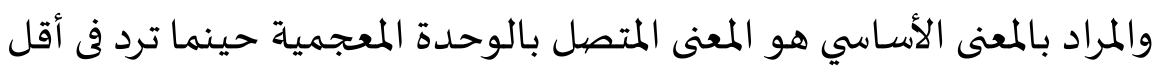

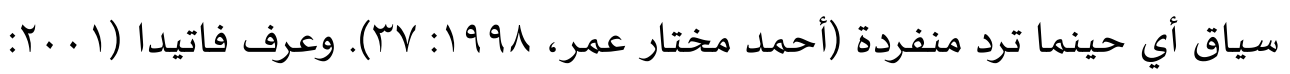

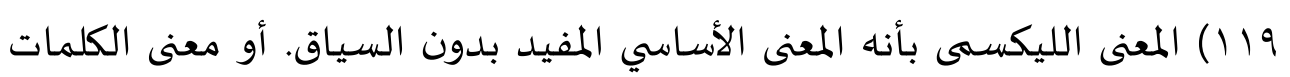
حينما كانت منفردة لأنها إذا تركبت مع الكلمات الأخرى يتغير معناها. ب. المعنى الإضيافي (AdditionalMeaning)

المعنى الإضافي أو العرضي أو الثانوي أو التضمني وهو المعنى الذي يملكه

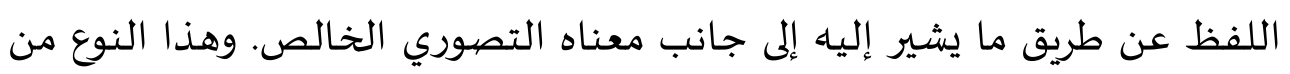

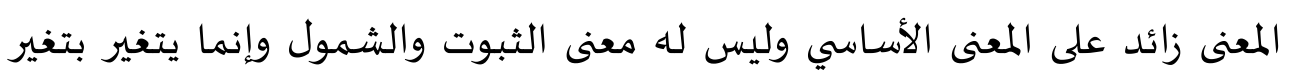

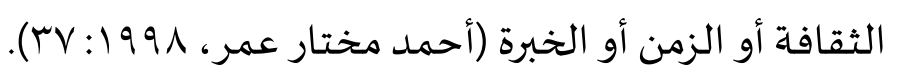

ج. المعنى الأسلوبي (Stylistic Meaning)

يظهر المعنى الأسلوبي بوجود العلاقة بين عبارة وسياق (فاتيدا، ل ـ ـ ؟: 7 1 1).

وهذاالنوع من المعنى الذي تحمله قطعة من اللغة بالنسبة للظروف الاجتماعية

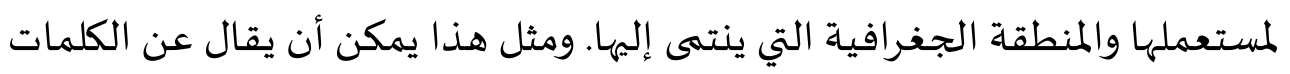

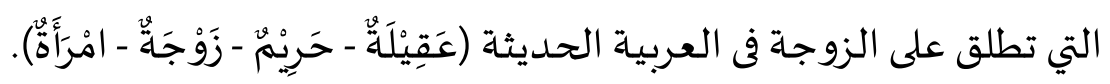

المعنى الأسلوبي كما قال فاتيدا قد أثرت عليه الأشياء الآتية :

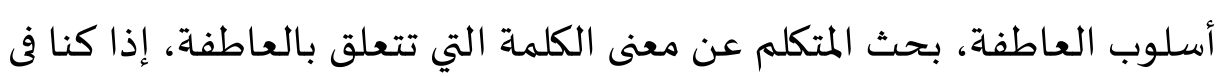

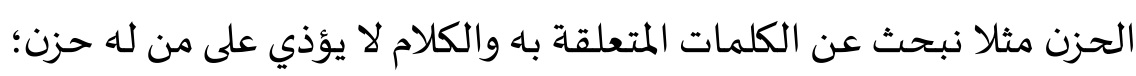
r) أسلوب الأغراض، الأغراض مثلا للسؤال لابد للمتكلم من مراعاة الكلمات

$$
\text { ع) أسلوب المتعلقة باء؛ أسلوب المكاب؛ المكان. }
$$


د. المعنى النفسي (Subjective Meaning) المعنى النفسي هو ما يشير إلى ما يتضمنه اللفظ من دلالات عند الفرد. فهو بذلك معنى فردي ذاتي. هناك فرق بين المعنى النفسي والمعنى الإدراكي كما في الجمل منال الآتية : بالب معبs

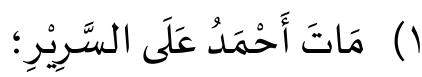

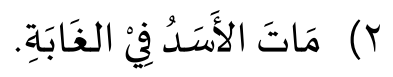

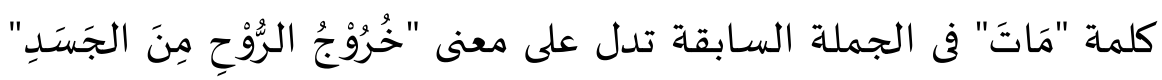

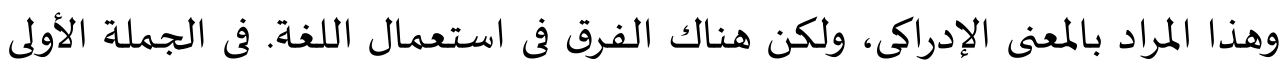

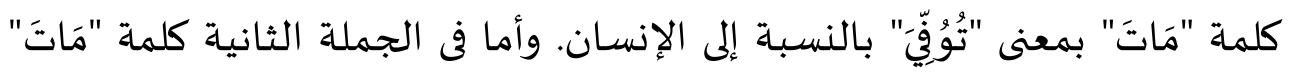

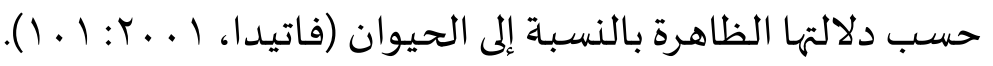

$$
\begin{aligned}
& \text { هـ المعنى الإيحائي (Collocative Meaning) }
\end{aligned}
$$

المعنى الإيحائي هو الذي يتعلق بكلمات ذات مقدرة خاصة على الإيحائي نظرا

$$
\text { لشفافيتها. المعنى الإيحائي متأثر بالأشياء الآتية: }
$$

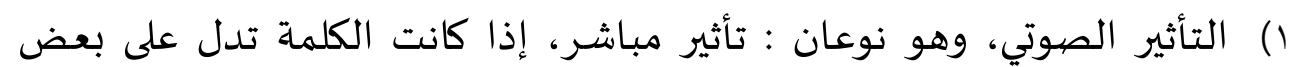

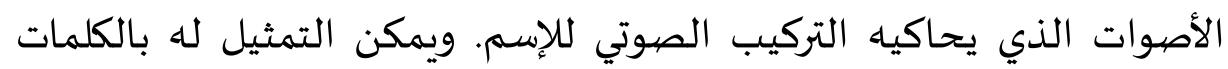

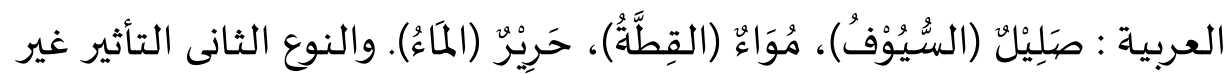

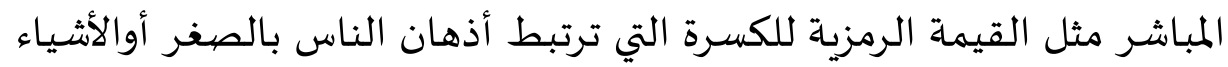

$$
\text { الصغيرة؛ }
$$

r التأثير الصرفي، يتعلق بالكلمات المركبة والكلمات المنحوتة كالكلمة العربية

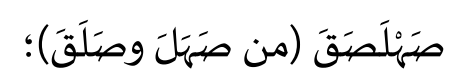

r) التأثير الدلالي، يتعلق بالكلمة المؤسسة على وهلى المجاز أي صورة كلامية معبرة.

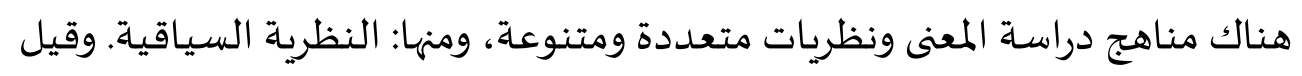

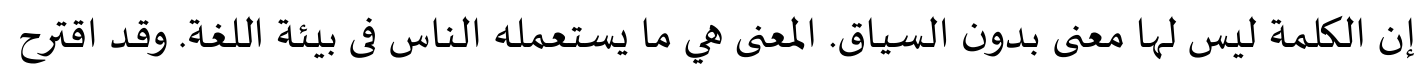
K. Ammer أ. السياق اللغوي (Linguistic Context)

السياق اللغوي يمكن التمثيل له بكلمة "good" الإنجليزية (ومثلها كلمة

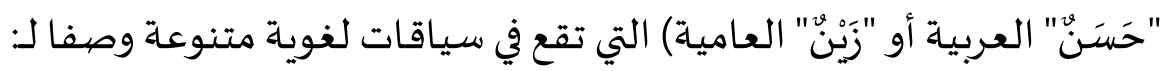


Ta'Cim al-'Arabiyyah : Jurnal Pendidikan Bahasa Arab dan Kebahasaaraban, 2 (2), 2018

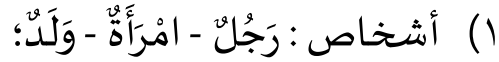

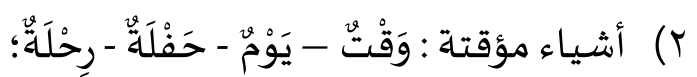

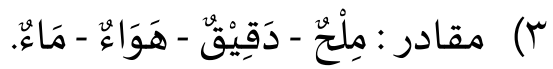

فإذا وردت في سياق لغوي مع كلمة "رَجُلْ" كانت تعني الناحية الخلقياة، وإذا وردت وصفا لطبيب مثلا كانت تعني التفوق في الأداء (وليست الناحية الأخلاقية)، وإذا وردت وصفا للمقادير كان معناها الصفاء والنقاوة.

ب. السياق العاطفي (EmotionalContext)

السياق العاطفي يحدد درجة القوة و الضعف في الانفعال، مما يقتضي

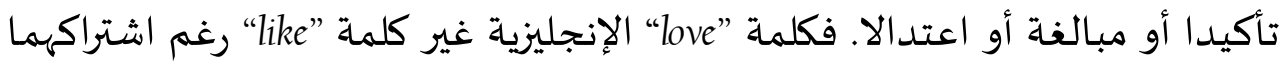

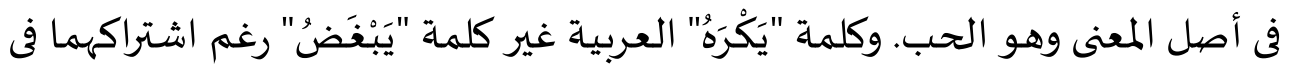

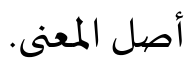

السياق الموقفي (SitutionalContext) ج

سياق الموقف يعنى الموقف الخارجي الذي يمكن أن تقع فياء الكلمة. مثل

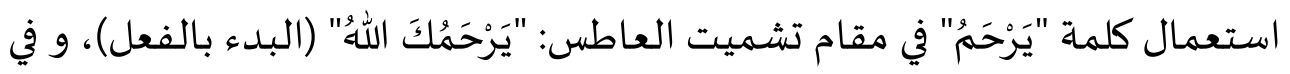

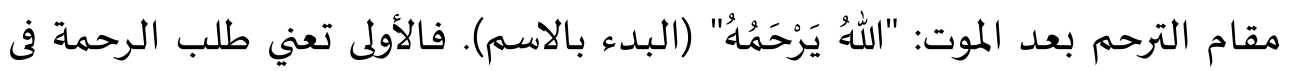

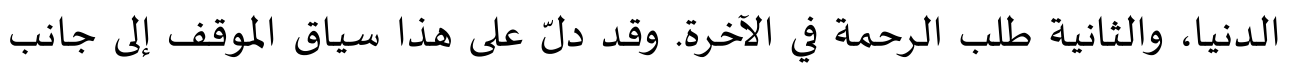
السياق اللغوي المتمثل في التقديم و التأخير. د. السياق الثقافي (CulturalContext) السياق الثقافي يقتضي تحديد المحيط الثقافي أو الاجتماعي الذي يمكن أن أن النمافي

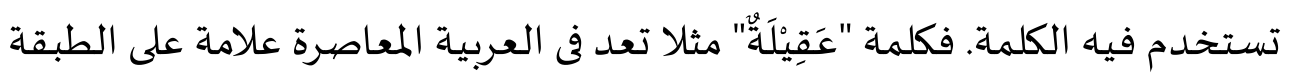
الاجتماعية المتميزة بالنسبة لكلمَة "زَوْجَةُّ".

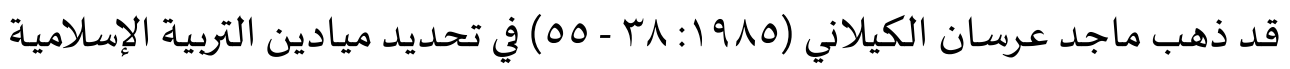

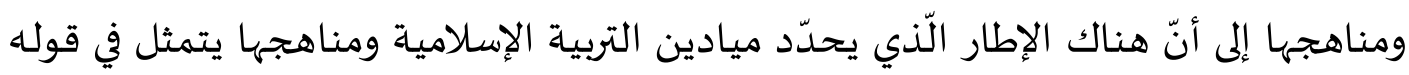

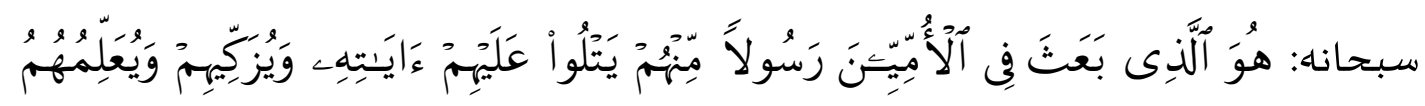

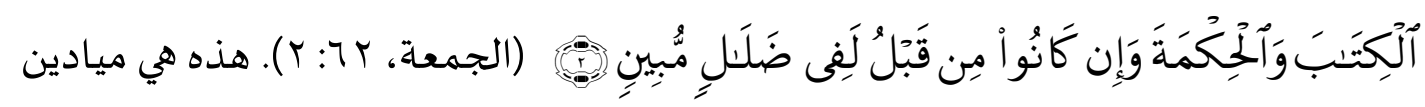

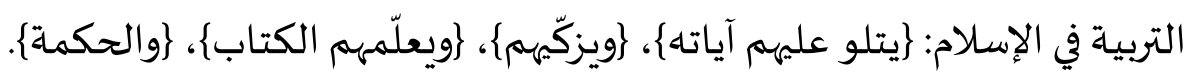


إننا على علم أن المربي أو المعلّم من عناصر التربية الإسلامياة، فقد أشار القرآن إلى

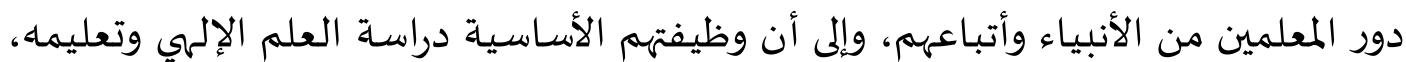

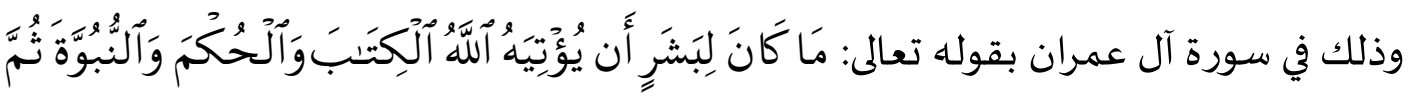

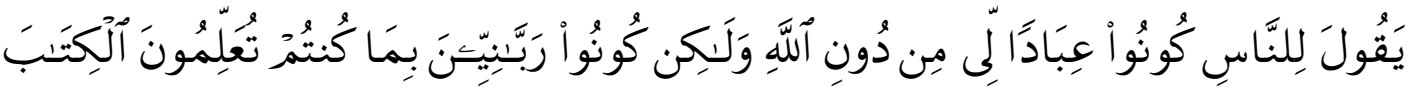

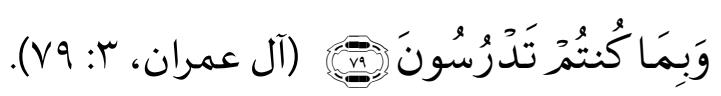

وأشار جل جلاله إلى أن من أهم وظائف الرسول صلى الله عليه وسلم تعليم الناس

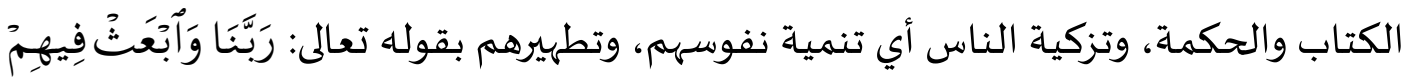

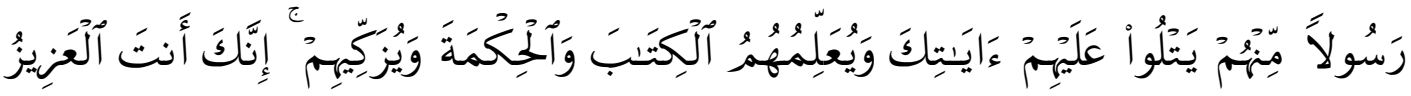

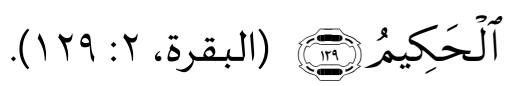

وقد بلغ من شرف مهنة التعليم أن جعلها الله من جملة المهمات التي كلف بها رسوله

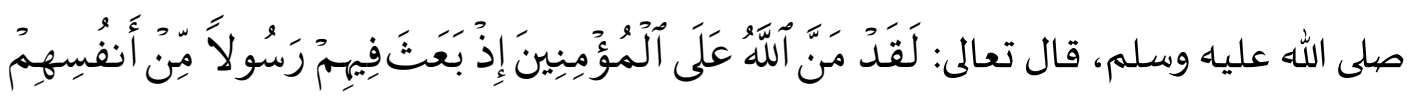

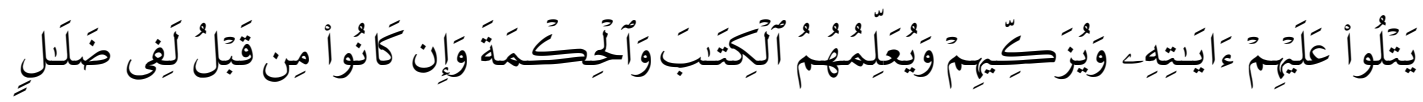

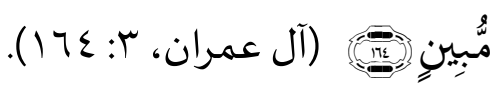

ويتضح من هذه الآيات أن للمربي وظيفتين أساسيتين هما:

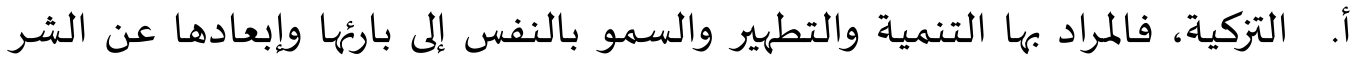

$$
\text { والمحافظة على فطرتاء؛ }
$$

ب. التعليم، وهو نقل المعلومات والعقائد إلى عقول المؤمنين وقلوبهم ليطبقوها في

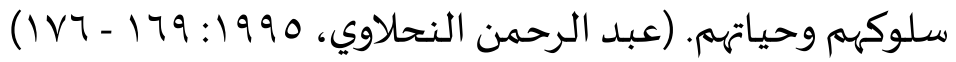

r. المعانى المعجمية لألفاظ التلاوة والتزكية والتعليم

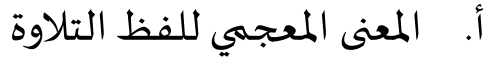

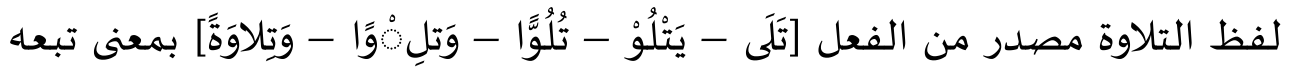

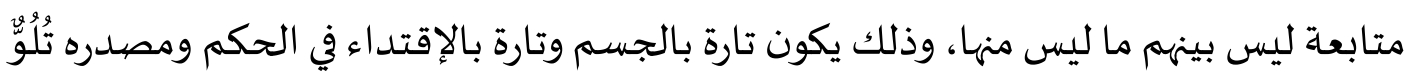

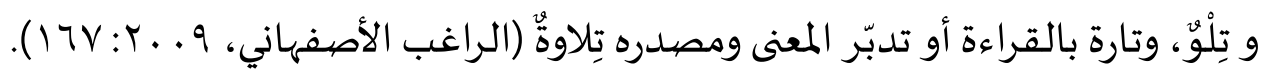


أبرز محمد محمد داود في كتابه معجم الفروق الدلالية في القرآن الكريم (^ ـ. .؟:

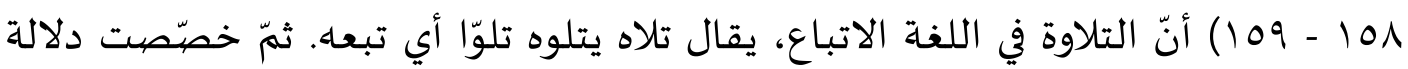

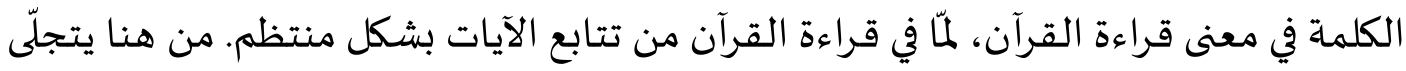

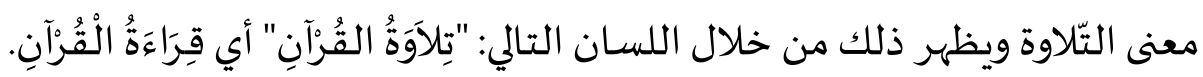

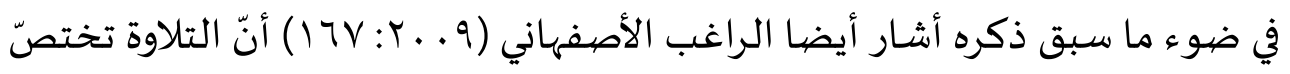

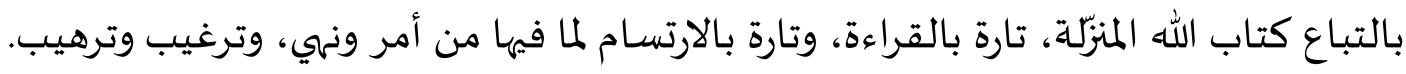

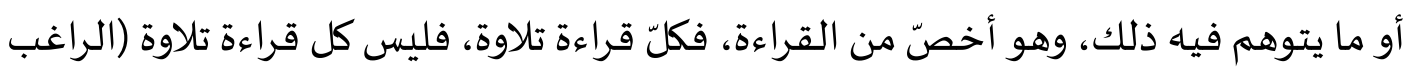

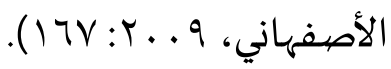

نتيجة لكل ما سبق أن التلاوة أخصّ من القراءة إذ هي قراءة واتباع معا.

ب. المعنى المعجمي للفظ التزكية

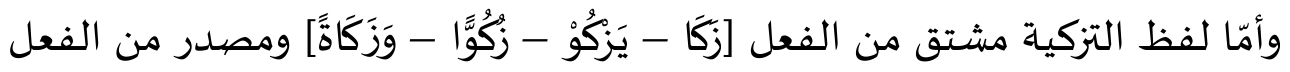

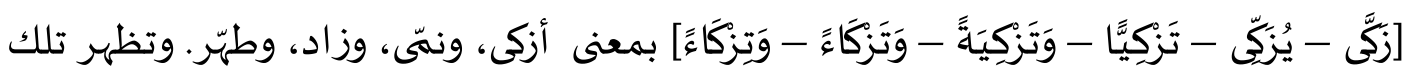

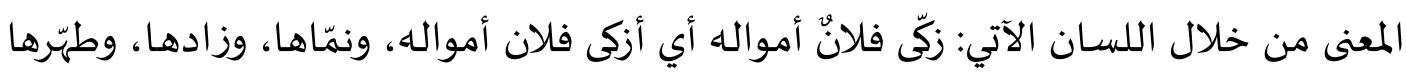

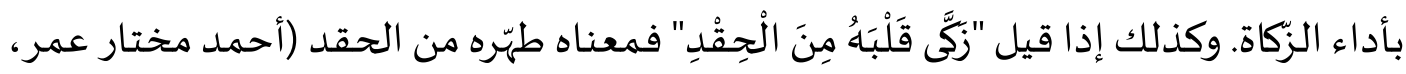

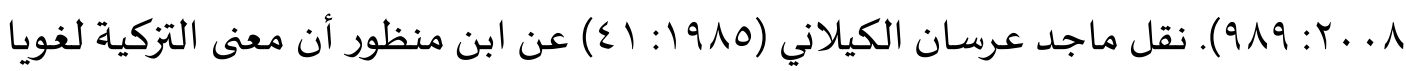

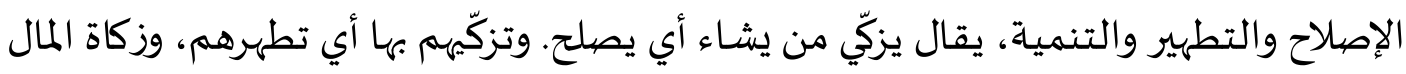

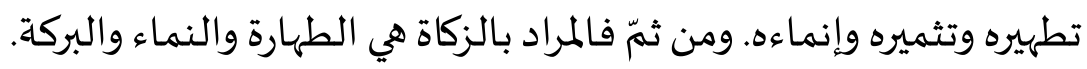
والنتيجة لما قد سبق بيانه أن لفظ التزكية يشتمل على دلالات لغوية متعدددة، تشير جميعها إلى ما ينبغي أن تتضمّنـه من أنشطة الإصلاح والتنمية والتطهير. ج. المعنى المعجمي للفظ التعليم

قبل أن يضيع معنى لفظ التعليم معجميّا، يقول أنّ لفظ التعليم مصديدر من الفعل

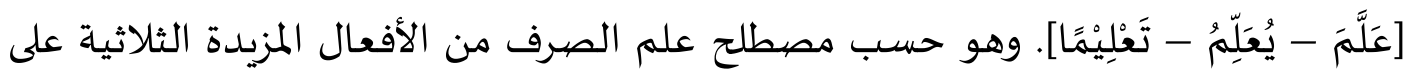

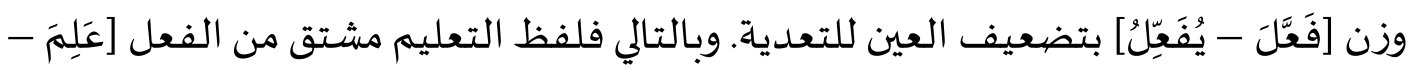

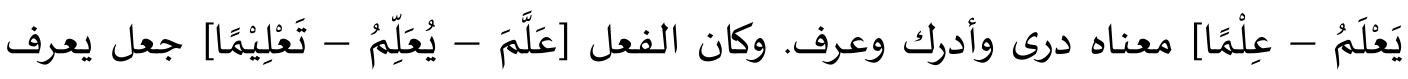

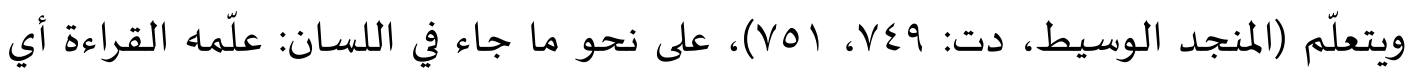

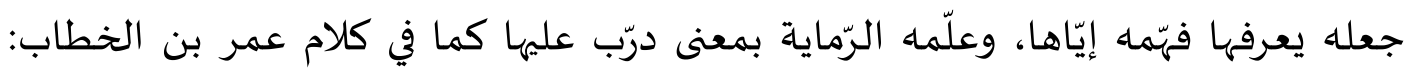

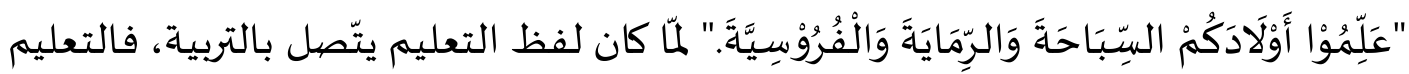


فرع من التربية يتعلق بطرق تدريس الطلاب أنواع المعارف والعلوم والفنون (أحمد مختار

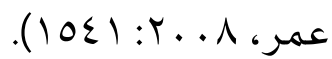
أبرز الراغب الأصفهاني في كتابه مفردات ألفاظ القرآن (9 . .ب: . ـ10) أنّ التعليم

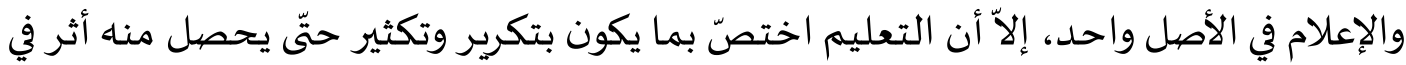

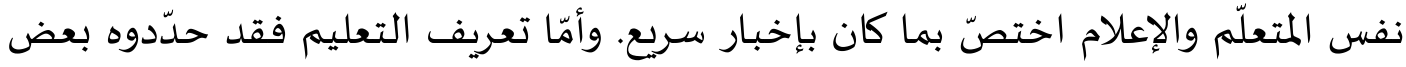

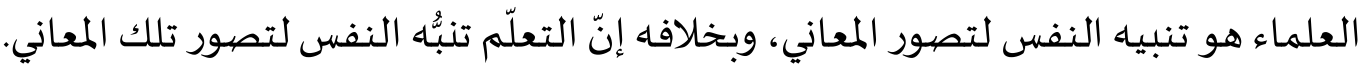

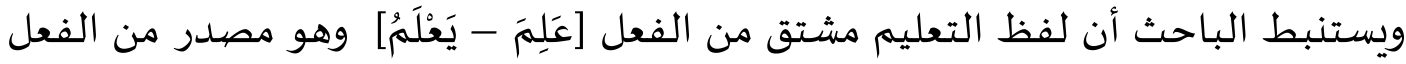

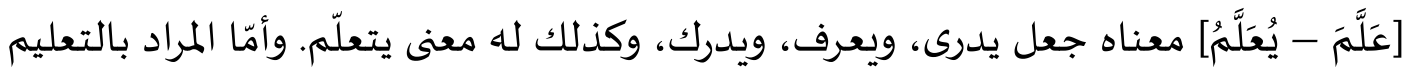
هو تنبياه نفس المتعلم لتصور المعاني لذهناه بتكرير وتكثير حتى يحصل منـه أثر في نفسـها.

r. المعاني السياقية لاندماج ألفاظ ثلاثة متماسكة مندمجة وهي التلاوة والتزكية والتعليم نظرا إلى تفسيرها في الآيات القرآنية هي كما يلي: أ. أ. معنى لفظ التلاوة

وفي الآيات السابقة التي تكررت في أربعة مواضع من القرآن المجيد مع اختلاف بسيط في الآداء اللفظي أو ترتيب ألفاظها، أن لفظ التلاوة يعقبه لفظ آية كما في قوله جله جلّ جلالها:

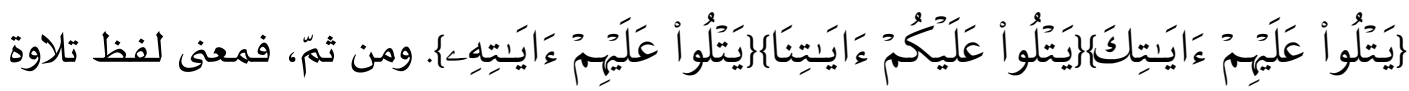
الآيات هي قراءة القرآن المجيد أو ما توحى من العلامة الدالة على وحدنية الله جلّ جلاله وعظيم قدرته وبديع تصرفه في السموات والأرض وتوجيه النفوس إلى الاستفادة مناه والاعتبار

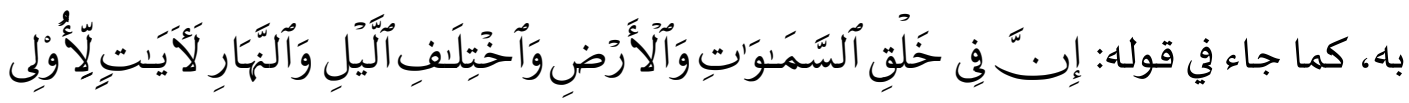

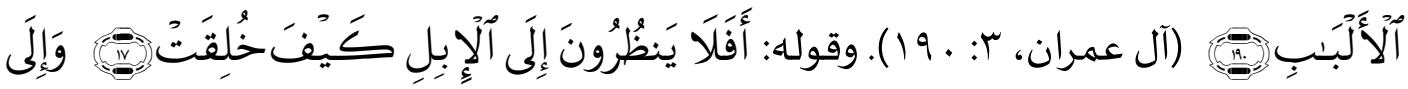

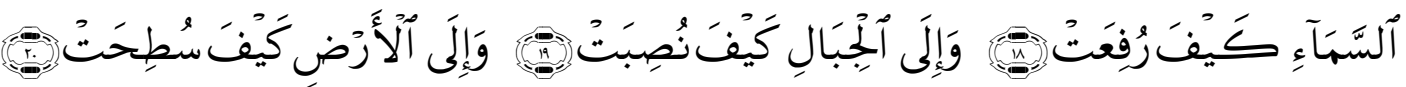

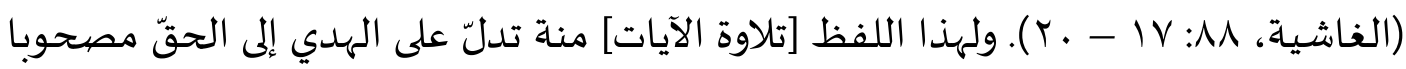

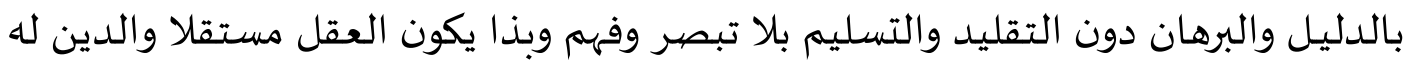
مرشـا وهاديا.

وقد سمي القرآن بآيات لأنّ الآيات جمع آية وهي الجملة من جمل القرآن الكريم. وكان كل واحدة من جمل القرآن دليـل على صدق الرسول من حيث بلاغة اللفظ وكمال المعنى. 


\section{ب. معنى لفظ التزكية}

لقد حاول المفسرون تفسير معنى هذا اللفظ - كما سبقت الإشـارة إليه -، ومن ثمّّ، مهرديه

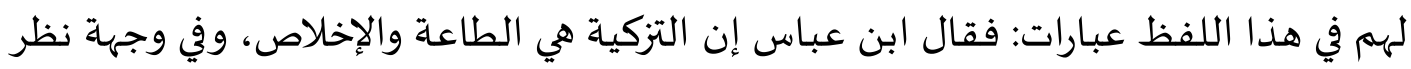
ابن جريح هي التطهير من الشرك، وقيل الأمر بالزكاة التي تكون سببا للطهرة، وقيل هي إني

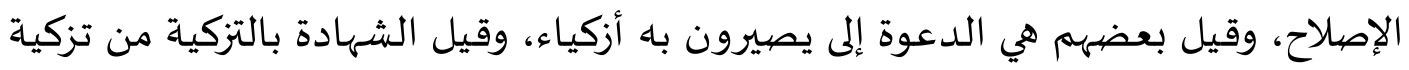

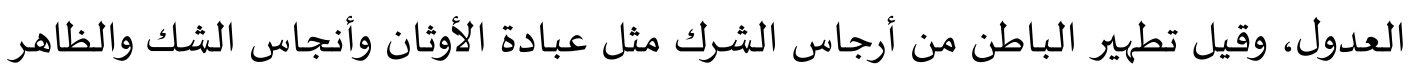

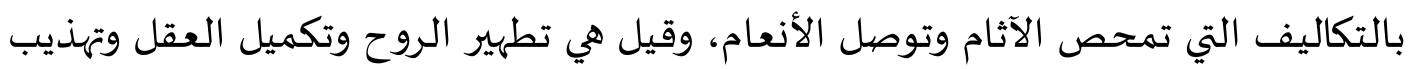
الأخلاق، وقيل هي تطهير النفوس من رذائل الأخلاق وانحرافات الجاهلية.

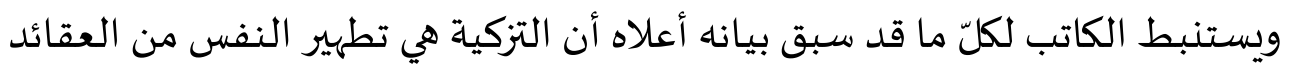
الزائفة ووساوس الوثنية وأدراهها ورذائل الأخلاق وانحرافات الجاهلية. ج. معنى لفظ التعليم من الآيات السـابقة التي تكررت في أربعة مواضع تبدو وضيحا أنّ لفظ التعليم تليه

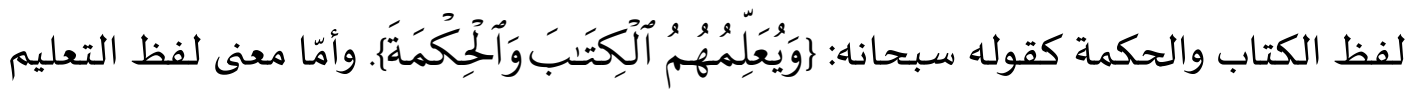
الّذي يقرنه لفظ الكتاب فهو تفهيم ألفاظ القرآن والأمر بحفظ ألفاظه ونظمها لتكون معانيه

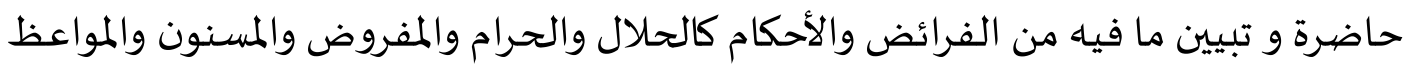

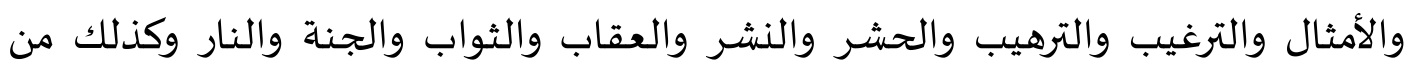
السنن وشرائع الأنبياء.

وقبل أن يضع معنى لفظ التعليم الّذي يقرنه لفظ الحكمة، يقال إنّ عطف الحكمة الحماء

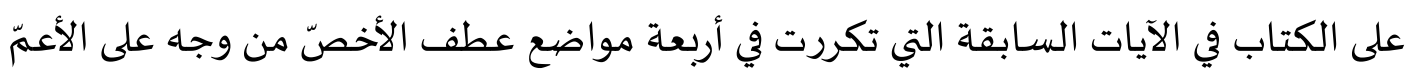

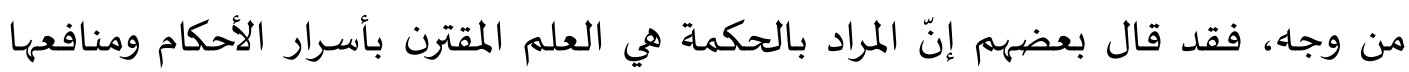

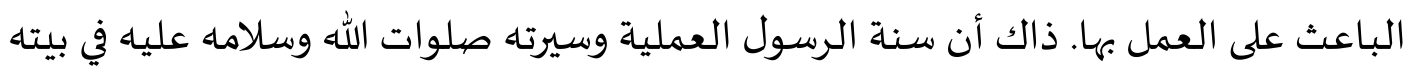

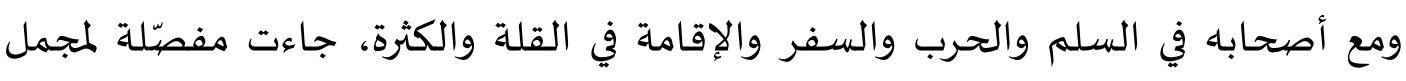
القرآن ومبينة لمبهمه وكاشفة لما في أحكامه من الأسرار والمنافع. وباختصهار القول إن وإن تعليم الحكمة هو الإرشاد العملي. ع. التضمين التربوي من معاني ألفاظ التلاوة والتزكية والتعليم في القرآن الكريم

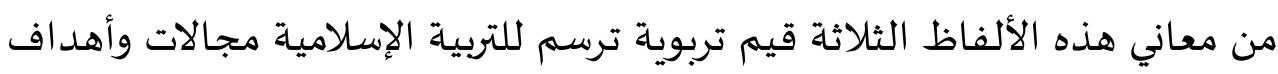

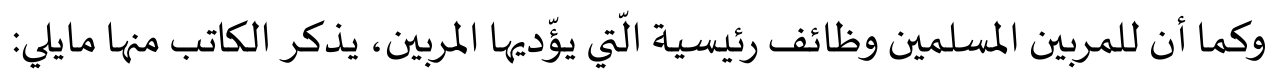




$$
\text { أ. مجالات التربية الإسلامية وأهد افها }
$$

قد سبق البيان أنّ الآيات السـالفة التي تكررت في المواضع الأربعة من القرآن الكريم تتمثل الإطار الّذي يحدد مجالات التربية الإسلامية وأهدافها. ويقتصر هذا الإطار حقيقيا على اندماج الألفاظ الثلاثة المندمجة هي التلاوة والتزكية والتعليم. وقد لاحظ أنّ لفظ التلاوة

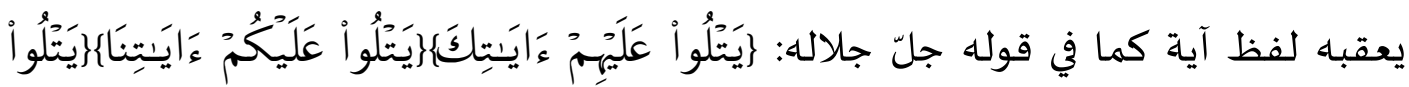

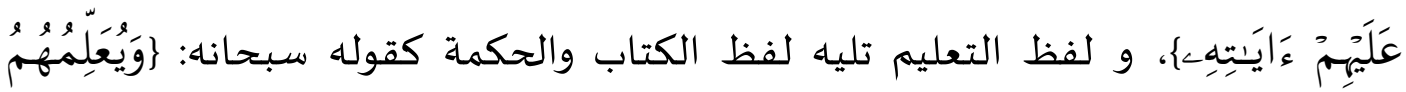

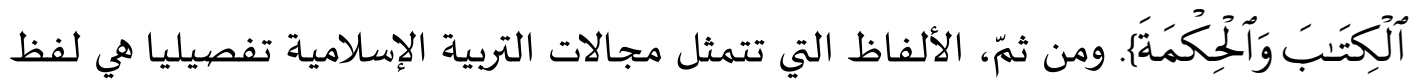
تلاوة الآيات والتزكية وتعليم الكتاب وتعليم الحكمة. أمّا مضيامين كل الألفاظ فهي كما في النقاط التالية:

\section{() لفظ تلاوة الآيات اللّني يعبّر عن مجال العقيدة الإسلامية}

عرف أنّ لهذا اللفظ معنى قراءة القرآن المجيد أو ما توحى من العلامة الدالة على وحدنية الله جلّ جلاله وعظيم قدرته وبديع تصرفه في السموات والأرض وتوجيـا النفوس إلى الاستفادة منـاه والاعتبـار باه. عرف لهذا المعنى أنّ الغرض من بعثة الرسول صلى الله عليه وسلّم لا يعتمد على قراءة آيات القرآن وحدها، بل يتناول أيضيا توجيه النفوس إلى الإستفادة منها والاعتبار بها بصدد غرس عقيدة التوحيد والاتجاهات

$$
\text { الإيمانياة في قلوب الأمّة. }
$$

في ضوء ما سبق ذكره أشـار ماجد عرسـان الكيلاني (910 1: 1 ع) أنّ قوام تنفيذ التربية الاسالامية لابدّ من تكوين إيدولوجية عقائدية هدفها غرس عقيدة التوحيد وتمكين الولاء للإسلام بين المتعلمين وغرس الاتجاهات الإيمانياة في قلوبهم وتوجيهها إلى اعتقاد بكمال التوجياه الإلهي في جميع نشطات الحياة.

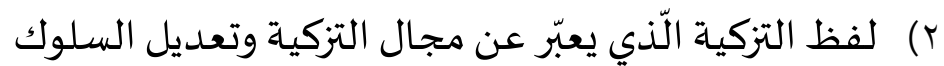

قد سبق البيان أنّ المعنى المعجمي للفظ التزكية هو ما ينبغي أن تتضهمّنـه من أنشطة الإصلاح والتنمياة والتطهير، وأمّا المعنى السياقي لهذا اللفظ فهو تطهير النفس من العقائد الزائفة ووساوس الوثنية وأدرانها ورذائل الأخلاق وانحرافات الجاهلية. ومن ثمّ، فمجال التزكية هذه تبدأ التطبيقات التربويـة بانتزاع ابتعاد المتعلم عن البيئات الّي تتنكر للقيم الإسلامياة. ويعقب هذا الانتزاع خطوة أخرى قوامها التعرّف 
على مؤثرات التربية غير الإسلامية في الفرد والّتي تتمثل في ألوان كثيرة من السلوك

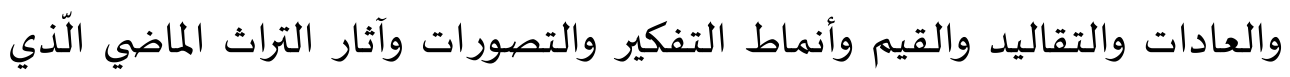

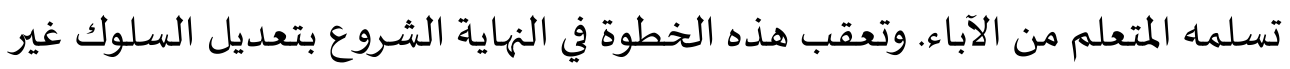

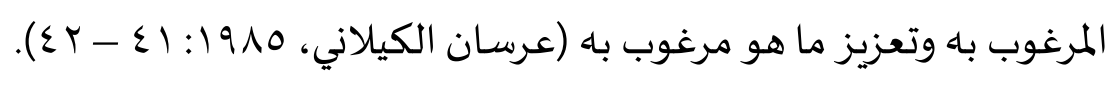

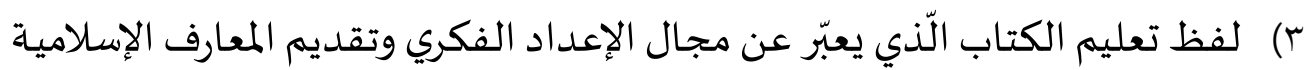

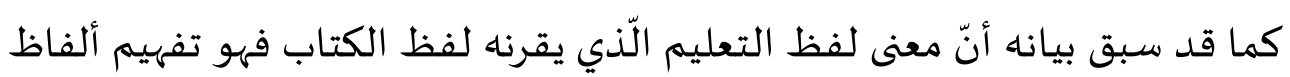

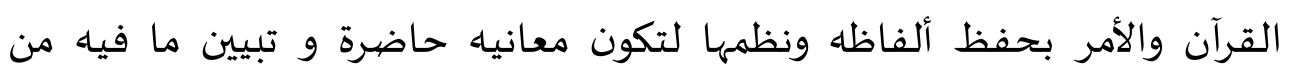

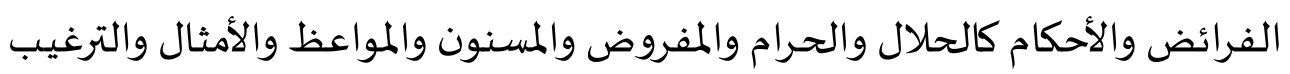

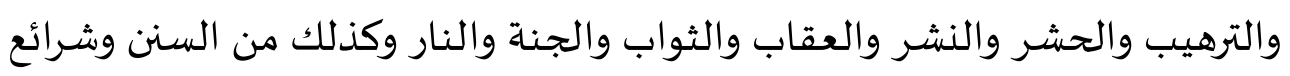
الأنبياء. من هنا يتجلّى المعنى الجوهري لهذا اللفظ هو التفهيم ما في القرآن من محتوياته

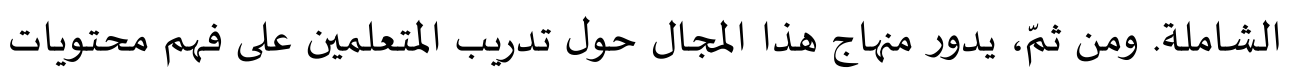

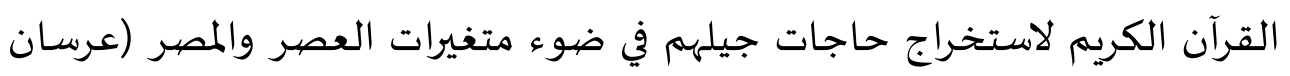

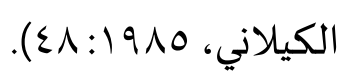

وباختصار القول أنّ هذا مطابق بغرض بعثة الرسول صلّى الله عليه وسلم وهو التبيين ما في القرآن من ظواهر الشريعة.

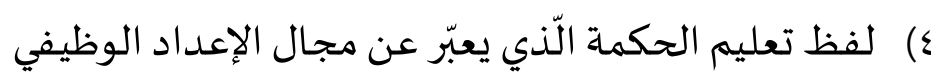
بيّن فيما سبق أنّ معنى تعليم الحكما باختصار القول إرشاد عملي. إذا كان القرآن

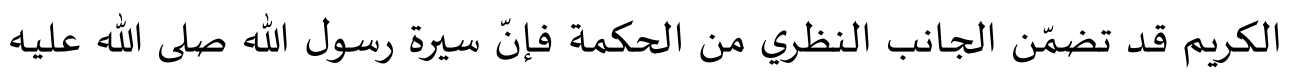

$$
\text { وسلّم تقدم الجانب العملي. }
$$

من البيان السـابق يبدو أنّ هناك ثلاتة أهداف من التربية الإسلامية وهي (1) التربية العقائدية؛ و (r) التربية الخلقية؛؛ و (r) التربية الفكرية.

ب. وظائف المربّى وواجباته الأسـاسية 
يتضح من هذه الآيات أنّ للمعلّم وظائف شتّى تقتصر حقيقيا على ألفاظ التلاوة والتزكية والتعليم كما في النقاط التالية:

1) التلاوة

وفي الآيات السابقة التي تكررت في أربعة مواضع من القرآن المجيد مع اختلاف بسيط

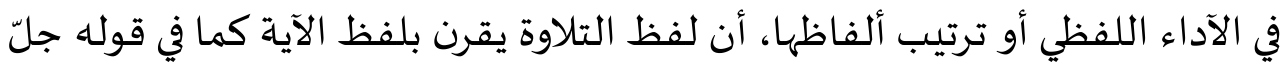

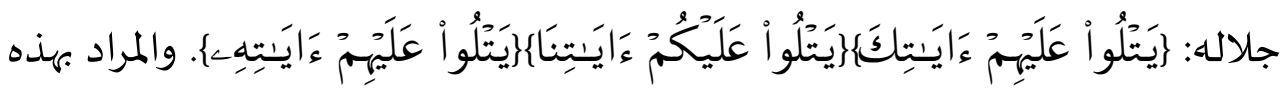
الوظيفة لابد للمعلّم أو المربّي من اكتشـاف ظواهر عظمة الآلهة الواردة في المواد

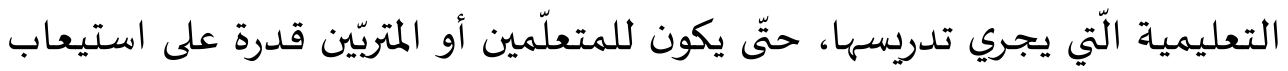

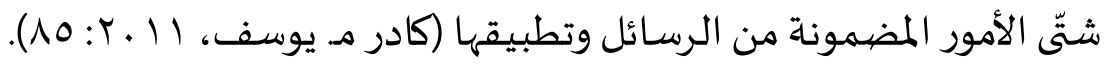
r) التزكية

ويشتمل لفظ التزكية على دلالات لغوية متعددة في معانيا المعجمياة، تشير جميعها

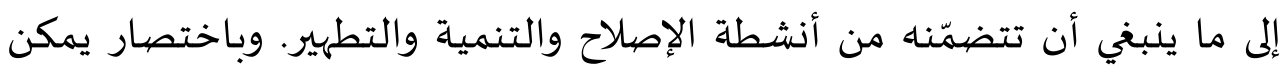

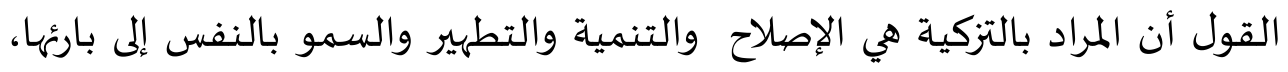
وابعادها عن الشر والمحافظة على فطرتها.

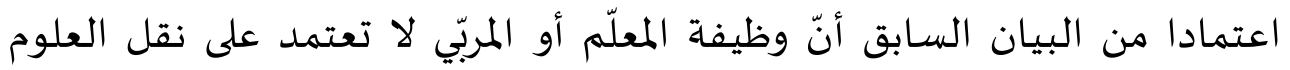

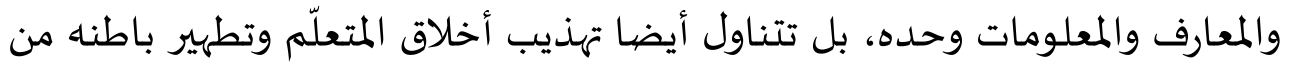

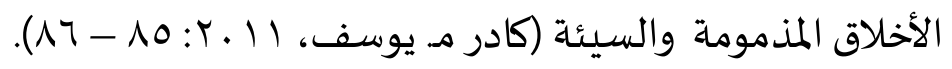
r) (ب التعليم

وفي الآيات السابقة التي تكررت في أربعة مواضع من القرآن المجيد مع اختلاف بسيط

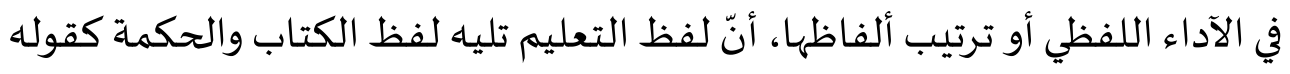

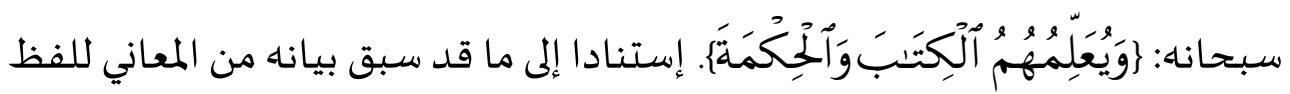
تعليم الكتاب والحكمة يبدو أن من وظائف المعلّم أو المربّي تعليم ما في القرآن من

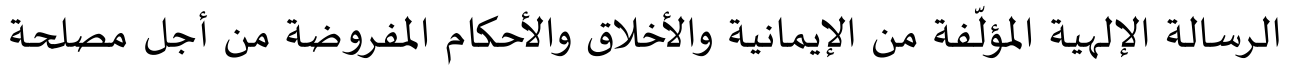

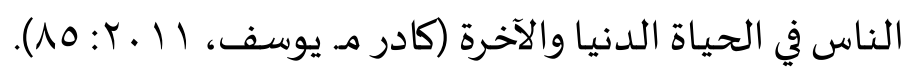




\section{النتائج}

وبعدما حلل الباحث ألفاظ التلاوة والتزكية والتعليم حصل على النتائج منها: (1) أن

لفظ التلاوة بمعنى القراءة والاتباع، وذلك يكون تارة بالقراءة أو تدبر المعنى وتارة بالارتسام

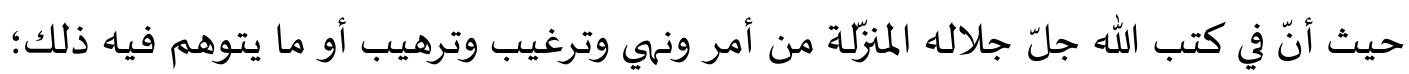

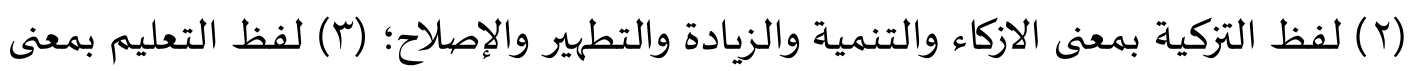
جعل الدراية والادراك، وذلك اختصّ بما يكون بتكرير وتكثير حتّى يحصل منه أثر في النفس.

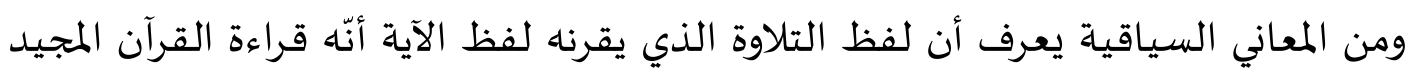

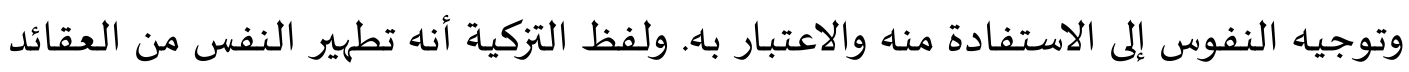

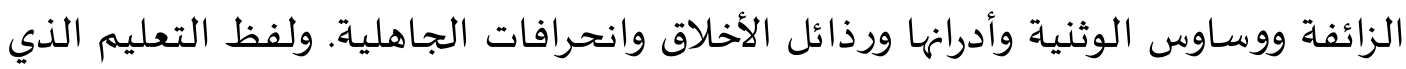

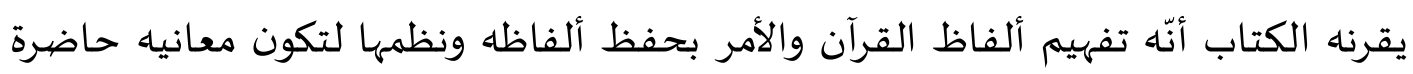

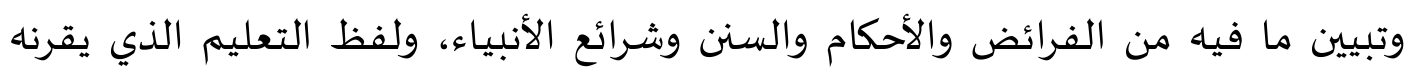

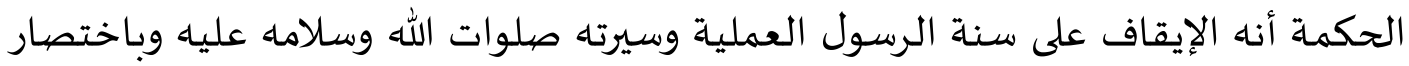

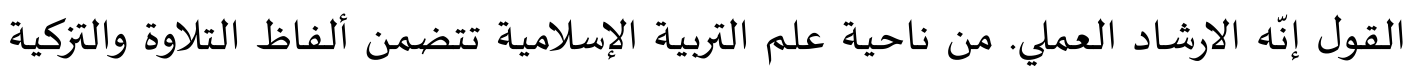

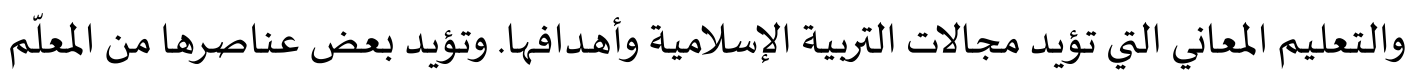

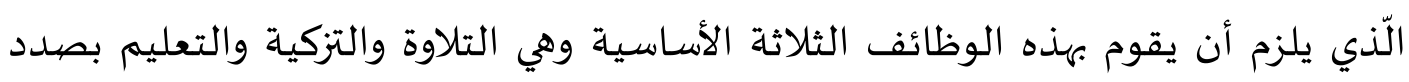

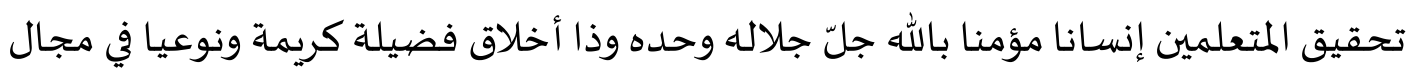
معرفي.

\section{المراجع}

أبو عبد الله محمد بن أحمد الأنصاري القرطبي. ؟ ...r. الجامع للأحكام القرآن. رياض: دار عالم الكتب

أبو عبد الله محمد بن عمر بن الحسن بن الحسين التيمي الرازي الملقب بفخر الدين الرازي. 199. مفاتيح الغيب. بيروت: دار الفكر.

أحمد مصطفى المراغى. 9 أ. تفسير المراغى. مصر: شركة مكتبة ومطبعة مصطفى البابى ئىوري الحلبى وأولاده 
Ta'lim al-'Arabiyyah : Jurnal Pendidikan Bahasa Arab dan Kebahasaaraban, 2 (2), 2018

أسعد محمود حومد. 9 . . ؟. أيسر التفاسير (تفسير - أسباب النزول - أحاديث - نماذج إعراب). دمشق: جميع الحقوق محفوظة للمؤلف

أبي الحسن علي بن أحمد الواحدي النيسابري. ع991. الوسيط في تفسير القرآن المجيد.

$$
\text { بيروت: دار الكتب العلمية }
$$$$
\text { أحمد مختار عمر. ـ1991. علم الدلالة. القاهرة: دار الإحياء التراث العربي }
$$

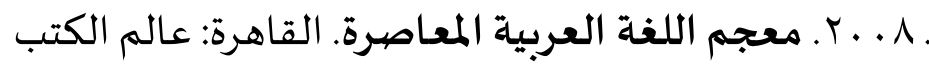

الراغب الأصفهانى. 9 . . r. مفردات ألفاظ القرآن الكريم. بيروت: دار الفكر أنطوان نعماه وعصام مدوّر ولويس عجيل ومتري شمّاس. ب. . .؟. المنجيد الوسيط في اللغة

$$
\text { المعاصبرة. بيروت: دار المشرق }
$$

أوريل بحر الدين. II ــr. مهارات التدريس نحو إعداد مدرس اللغة العربية. مالانق: مطبعة جامعة مولانا مالك إبراهيم الإسلامية الحكومية بمالانق

عبد الرحمن النحلاوي. V... . أصول التربية الإسلامية وأسـاليها في البيت والمدرسة والمجتمع، المكتبة الشاملة

علاء الدّين علي بن محمّّد بن إبراهيم البغدادي. ع . . r. تفسير الخازن المسمّى لباب التأويل في معاني التّنزيل. بيروت: دار الكتب العلمياة

علي أحمد مدكور. r . .r. منهج التربية الإسلامية في التصور الإسلامي. القاهرة: دار الفكر

$$
\text { العربي }
$$

فريد عوض حيدر. 0 . . . علم الدلالة. القاهرة: مكتبة الأداب

ماجد عرسان الكيلاني. 1910 . تطور مفهوم النظرية التربوية الإسلامية، دراسة منهجية في الأصهول التاريخية للتربية الإسلامية. المدينة المنوّرة: مكتبة دار التهوير محمد الطاهر ابن عاشور. ع191 ـ تفسير التحريروالتنوير. تونس: الدار التونسية للنشر محمد فؤاد عبد الباقى. بدون التارتخ. المعجم المفهرس لألفاظ القرآن الكريم. بيروت: دار الفكر 
. . . . . . معجم الفروق الدلالية في القرآن الكريه، لبيان الملامح الفارقة بين

الألفاظ متقاربة المعنى والصيخ والأسـاليب المتشـابهة. القاهرة: دار غريب مقاتل. r · . r. مقاتل بن سليمان. بيروت: مؤسسـة التارتخ العربي مناع خليل القطان. سو9 1. مباحث فى علوم القرآن. بيروت: منشورة العصر الحديث شهاب الدين محمود ابن عبدالله الألوسى البغدادي. بدون التاريخ. روح المعاني في تفسير

$$
\text { القرآن العظيم والسبع المثاني. بيروت: احياء التراث العربي }
$$

نصر بن محمد بن أحمد بن ابراهيه السـمرقندي. س99 19. تفسير السمرقندي المسـمّى بحر

$$
\text { العلوم. بيروت: دار الفكر العربي بري }
$$

. . . . . . معجم الفروق الدلالية في القرآن الكريم، لبيان الملامح الفارقة بين

$$
\text { الألفاظ متقاربة المعنى والصيخ والأسـاليب المتشـابهة. القاهرة: دار غريب }
$$

مقاتل. ץ . . †. مقاتل بن سليمان. بيروت: مؤسسـة التارتخ العربي

$$
\text { مناع خليل القطان. بV } 9 \text { ا ـ مباحث فى علوم القرآن. بيروت: منشورة العصر الحديث }
$$

شهاب الدين محمود ابن عبدالله الألوسى البغدادي. بدون التاريخ. روح المعاني في تفسير

$$
\text { القرآن العظيم والسبع المثاني. بيروت: احياء التراث العربي }
$$

نصر بن محمد بن أحمد بن ابراهيم السسمرقندي. سو 199 . تفسير السمرقندي المسمّى بحر

$$
\text { العلوم. بيروت: دار الفكر العربي. }
$$

Abdurrahman An-Nahlâwy. 1983. Usûl at-Tarbiyah al-Islâmiyyah wa Asâlibuhâ: fi al-bait, wa almadrasah, wa almujtama', Terj. Shihabuddin, Pendidikan Islam: Di Rumah, Sekolah dan Masyarakat. Jakarta: Gema Insani Press

Abuddin Nata. 2010. IImu Pendidikan Islam. Jakarta: Kencana Prenada Media Group

Ahmad Tafsir. 2004. Ilmu Pendidikan dalam Perspektif Islam. Bandung: PT Remaja Rosdakarya

Heri Khoiruddin. 2012. Ilmu al-Qur'an dan Perannya dalam Memahami alQur'an. Bandung: Fajar Media 
Ta'lim al-'Arabiyyah : Jurnal Pendidikan Bahasa Arab dan Kebahasaaraban, 2 (2), 2018

Kadar M. Yususf. 2011. Tafsir Tarbawi. Riau: Zanafa Publishing

Manna' Al-Qotton. tt, Mabahits fi Ulumil Qur'an, Terj. Aunur Rafiq El-Mazni. Pengantar Studi Ilmu al-Qur'an. Jakarta: Pustaka al-Kautsar

Mansoer Pateda. 2001. Semantik Leksikal. Jakarta: PT Rineka Cipta

Parera. 2004. Teori Semantik. Jakarta: Erlangga

Yaya Suryana dan Tedi Priatna. 2009. Metodologi Penelitian Pendidikan. Bandung: Azkia Pustaka Utama 